\title{
Physical Basis for Materials Synthesis Using Biomineralization
}

\author{
J. De Yoreo, C. Orme, P. Dove, H. Teng
}

May 16, 2000

U.S. Department of Energy

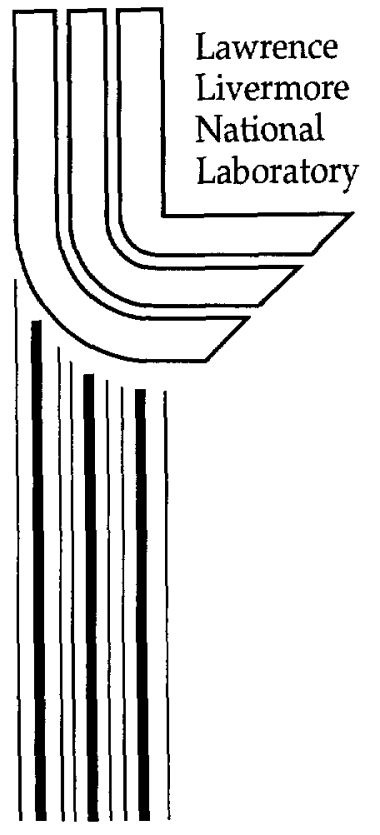




\section{DISCLAIMER}

This document was prepared as an account of work sponsored by an agency of the United States Government. Neither the United States Government nor the University of California nor any of their employees, makes any warranty, express or implied, or assumes any legal liability or responsibility for the accuracy, completeness, or usefulness of any information, apparatus, product, or process disclosed, or represents that its use would not infringe privately owned rights. Reference herein to any specific commercial product, process, or service by trade name, trademark, manufacturer, or otherwise, does not necessarily constitute or imply its endorsement, recommendation, or favoring by the United States Government or the University of California. The views and opinions of authors expressed herein do not necessarily state or reflect those of the United States Government or the University of California, and shall not be used for advertising or product endorsement purposes.

This work was performed under the auspices of the U.S. Department of Energy by the University of California, Lawrence Livermore National Laboratory under Contract No. W-7405-Eng-48.

This report has been reproduced directly from the best available copy.

Available electronically at http://www.doc.gov/bridge

Available for a processing fee to U.S. Department of Energy

And its contractors in paper from

U.S. Department of Energy

Office of Scientific and Technical Information

P.O. Box 62

Oak Ridge, TN 37831-0062

Telephone: (865) 576-8401

Facsimile: (865) 576-5728

E-mail: reports@adonis.osti.gov

Available for the sale to the public from

U.S. Department of Commerce

National Technical Information Service

5285 Port Royal Road

Springfield, VA 22161

Telephone: (800) 553-6847

Facsimile: (703) 605-6900

E-mail: orders@ntis.fedworld.gov

Online ordering: http://www.ntis.gov/ordering.htm

\section{OR}

Lawrence Livermore National Laboratory

Technical Information Department's Digital Library

http://www.llnl.gov/tid/Library.html 


\title{
PHYSICAL BASIS FOR MATERIALS SYNTHESIS USING BIOMINERALIZATION
}

\author{
97-LW-069 \\ Final Report
}

\author{
Jim De Yoreo and Christine Orme \\ Lawrence Livermore National Laboratory \\ Patricia Dove and Hui Teng \\ Georgia Institute of Technology
}

\section{Introduction}

Since the dawn of life on earth, organisms have directed the crystallization of inorganic ions from solution to form minerals that meet specific biological needs. The resulting materials often exhibit remarkable properties, making the processes involved in biomineralization of interest to a wide array of scientific disciplines. From a geochemical standpoint, perhaps the most important consequence is that $\mathrm{CaCO}_{3}$ biomineral formation occurs in the oceans on such a large scale that it influences many aspects of seawater chemistry and results in sequestration of carbon in the form of carbonate sediments. In this manner, the products of biomineralization are preserved in the rock record and serve as an extensive chronicle of the interplay between biota and the earth system environment.

From the point of view of materials synthesis, biological control over epitaxy is an elegant example of self-organization in complex molecular systems. Through selective introduction of peptides and proteins, ${ }^{1-6}$ living organisms deterministically modify nucleation, ${ }^{7,8}$ step kinetics, ${ }^{9-11}$ surface morphologies, ${ }^{12-15}$ and facet stabilities ${ }^{4,7,13,14}$ to produce nanophase materials, ${ }^{12,16}$ topologically complex single-crystals, ${ }^{3,6,17}$ and multi-layer composites. ${ }^{14,18}$ The resulting materials have biological functions as diverse as structural supports, porous filtration media, grinding and cutting tools, lenses, gravity sensors and magnetic guidance systems. As Table I shows, calcium carbonate minerals are ubiquitous amongst these biomineral structures. In addition, calcium carbonate is a well studied material that is easily crystallized and has known solution chemistry. Consequently, the calcium carbonate system provides an excellent model for investigating biomineralization processes. Surprisingly, in spite of the identification of carbonate biogenesis as a critical contributor to the carbon reservoir mediating climate change, and the enormous potential of biomimetic synthesis for production of tailored, crystalline nano- and micro-structured materials, the fundamental physical controls on carbonate biomineral formation remain poorly understood.

Carbonates are formed in diverse environments almost exclusively by living organisms ${ }^{19}$. These naturally occurring marine and fresh water minerals most commonly occur as the polymorphs of calcite, aragonite and vaterite which are nucleated and grown in the exoskeletons and tissues of marine and freshwater organisms ranging from simple bacteria and algae to crustaceans, molluscs, or sponges. It is known that the soluble fraction associated with mineralizing parts of organisms plays a primary role in crystal formation. In the formation of molluscan shells, this fraction is distinguished by the common presence of aspartic acid rich amino acid mixtures. ${ }^{2,20,21}$ It is also known that carbonates exposed to different polyamino acids exhibit different crystal habits. ${ }^{121,17}$ Belcher et al. ${ }^{22}$ showed that exposing growing $\mathrm{CaCO}_{3}$ crystals alternately to solutions containing polyanionic proteins associated with the aragonitic and calcitic layers of mollusc shells led to sequential switching of the crystal structure of the newly grown material between that of aragonite and calcite. Further work has demonstrated that these protein mixtures alter the morphology of the calcite growth surface ${ }^{23}$ and that they contain two fractions effecting growth: a step-binding fraction that inhibits step advancement on calcite surfaces, and a surface binding fraction that appears to lead to the subsequent nucleation of aragonite ${ }^{24}$. Wierzbicki et al. ${ }^{25}$ found that polyaspartate molecules ( $\mathrm{ASP}_{20}$ ) bind to calcite surfaces. ${ }^{25}$ Finally, modeling of $\mathrm{ASP}_{15}$ 
binding to calcite planes predicts large binding energies for well defined orientations. This and related evidence shows that systenlatic relationships between crystal morphology and surface interactions with the reactive groups of the organic molecules must exist. However, the interplay between surface chemistry and the physical processes of nucleation and crystal growth are poorly understood because, until recently, only ex situ biochemical studies focusing on the effect of changes in solution chemistry and/or surface stereo-chemistry on macroscopic crystal morphology had been performed.

Table I. Materials produced and strategies employed in biomineralizing or biomimetic systems

Approarch
$\begin{aligned} & \text { Nanoscale } \\ & \text { synthesis }\end{aligned}$

Crystal engineering

Microstructural fabrication

\author{
Product \\ Clusters, \\ Nanoparticles
}

Single crystals, Shaped composites

Mineral-polymer composites, Organized materials $\frac{\text { Systems }}{\text { Miccroemulsions }}$

Vesicles

Monolayers

Protein mixtures

Tublules

Fibers

Polyanionic peptides

Collagen
Polysiloxanes
Monolayers
Cellulose

\author{
Materials \\ $\mathrm{CaCO}_{3}, \mathrm{Fe}_{3} \mathrm{O}_{4}$ \\ $\mathrm{Pt}, \mathrm{Co}$, borides \\ $\mathrm{ZnS}, \mathrm{Ag}_{3} \mathrm{O}, \mathrm{Al}_{2} \mathrm{O}_{3}$ \\ $\mathrm{MnOOH}, \mathrm{FeS}$ \\ $\mathrm{CaCO}$
$\mathrm{NaCl}, \mathrm{CaCO}_{3}, \mathrm{BaSO}_{4}$
$\mathrm{Cu}, \mathrm{Ni}, \mathrm{Al}_{2} \mathrm{O}_{3}, \mathrm{Fe}_{3} \mathrm{O}_{4}$
$\mathrm{CuCl}, \mathrm{CaCO}_{3}, \mathrm{Fe}_{2} \mathrm{O}_{3}$
$\mathrm{CaCO}_{3}$
}

Ca-phosphates

$\mathrm{CaCO}_{3}, \mathrm{CaSiO}_{3}$

$\mathrm{Fe}_{2} \mathrm{O}_{3}$

$\mathrm{CaCO}_{3}$

Over the course of this project, we have focused on obtaining a microscopic understanding of the reaction mechanisms and physical controls on biomineralization, recognizing the fact that mineralization is, above all, a themodynamic phase transition. As such, rates of nucleation and growth as well as the resulting crystal structure, surface morphology, and habit are controlled by the the energetics and kinetics of adniolecules and steps on the crystal surface. Previous researchers have primarily focused on the morphological effects of organic modifiers and there steriochemical relationship to crystal structure. While understanding the stereochemistry is, undeniably, a vital step towards building a picture of the process of biomineralization, combining this knowledge with an understanding of the underlying physics is crucial to completing this picture and, moreover, to its successful application to materials technologies.

We began this project with a working hypothesis: Biomineralization of $\mathrm{CaCO}_{3}$ is successful because functional groups on protein chains are able to provide preferential sites for nucleation by changing the interficial energies and are able to alter growth rates and surface morphologies by selectively binding to kink sites on the $\mathrm{CaCO}_{3}$ surface. In order to test that hypothesis we used atomic force microscopy (AFM) to measure the energetic and kinetic factors controlling the growth of calcite stirfaces in both pure and acidic amino-acid bearing solutions. We also used self-assembled monolayers to investigate the role of surface chemistry in calcite nucleation. The attached publications review much of the work accomplished as part of this project. "Reversed calcite growth morphologies induced by microscopic kinetics: Insight into biomineralization" presents the results of kinetic studies on the pure calcite system. It contains the first detailed measurements of calcite kinetic parameters and indicates that trace impurity levels can lead to unexpected surface morphologies due to their anisotropic effect on step motion. "Kinetics of calcite growth: Surface processes and relationships to macroscopic rate laws" uses the results of our AFM investigations of the pure calcite system to link classical crystal growth theory with popular chemical affinity-based ritc laws derived from macroscopic studies of calcite crystallization. "Thermodynamics of calcite growth: Baseline for understanding biomineral 
formation" Describes our investigation of the thermodynamic state of the pure calcite surface and shows our initial results on calcite with aspartic acid. This paper presents the first measurement of the Gibbs-Thomson effect for steps on any crystal surface and uses the relationship between the thermodynamic parameters and the morphology to derive a hypothesize about the mechanism of aspartic acid modification of the surface. Results on calcite growth with chiral amino acids and calcite nucleation on self-assembled monolayers are summarized below (Manuscript in preparation).

\section{Chirality dependent interaction between calcite and simple amino acids}

The effect of glycine, aspartic acid and glutamic acid on step speed, critical length and
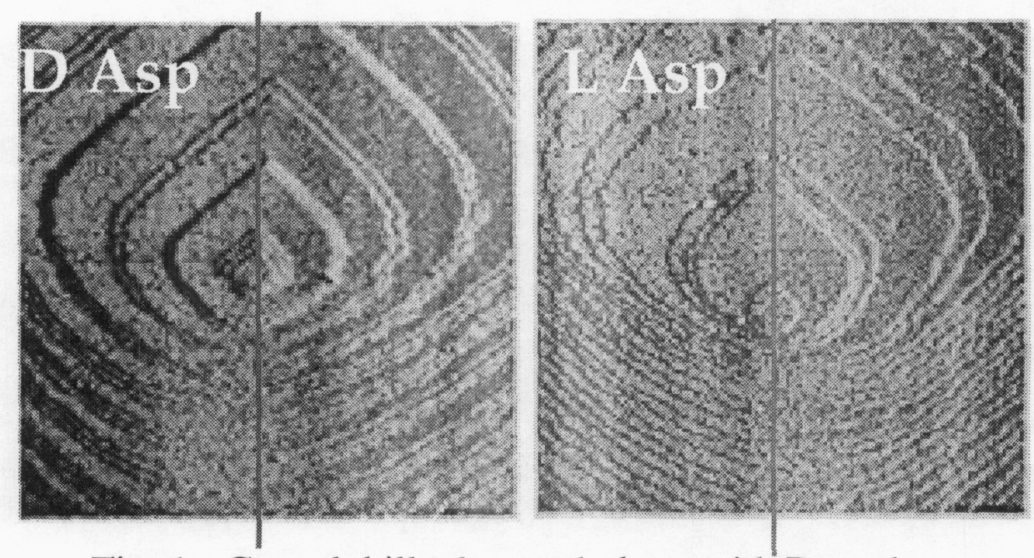

Fig. 1 - Growth hillock morphology with D- and L-aspartic acid
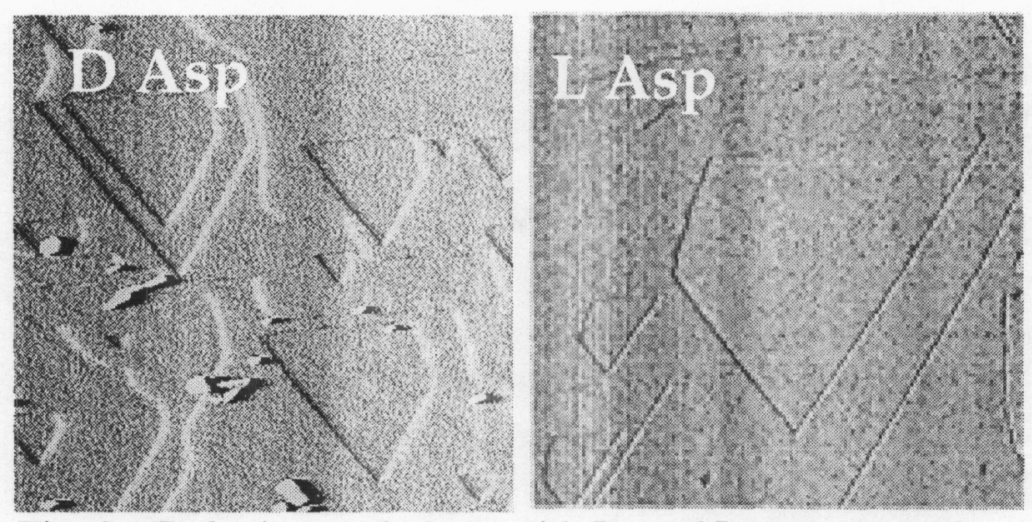

Fig. 2 - Etch pit morphology with D- and L-aspartic acid growth hillock, etchpit and crystal morphology was examined as a function of amino acid chirality and concentration. Addition of all amino acids during growth, led to stabilization of the (hk0) family of planes. When the amino acid had a chiral structure, the addition of pure $\mathrm{L}$-and D-forms resulted in anisotropic expression of these planes so that the resulting growth hillock, etchpits and crystal morphologies displayed mirror symmetry about the glide plane of calcite as shown for aspartic acid in

Figs. 1, 2 and 3. The addition of glycine, an achiral molecule, or D and L mixtures of aspartic and glutamic acid, led to symmetric forms as illustrated for glycine in Fig. 4. Because the overall facet shape exhibited the same shape as the growth hillocks, we were able to use the growth hillock geometry to construct the modified Wullf diagram for the orientational dependence of the step edge energy as shown in Fig. 5.

For any site on one side of the glide plane, an equivalent site on the other side can be found for which the geometric relationship with neighboring sites is related by mirror symmetry. Furthermore, the geometrical relationship between a single functional group of the amino acid with any single site on one side of the glide plane can be matched at the equivalent site on the other side. Consequently, the results of this study show unequivocally that the interaction of the amino acid with the calcite surface must involve both the chiral center of the amino acid (i.e., multiple groups) and multiple sites on the calcite surface. Through crystallographic modelling we showed that the differences between the geometrical relationship of $\mathrm{L}$ - and $\mathrm{D}$-aspartic acids to the calcite $\{104\}$ surface were subtly different, indicating that the energetic changes needed to drive the system from the D-induced to L-induced forms were small. This was consistent with the shallow character of the minima in the Wullf plot of Fig. 5.

In an attempt to experimentally determine the structural relationship between the adsorbed amino acid and the calcite surface, we recently performed in situ surface X-ray diffraction, NEXAFS and FTIR on calcite $\{104\}$ faces grown in the presence of aspartic acid. Despite the sub- 


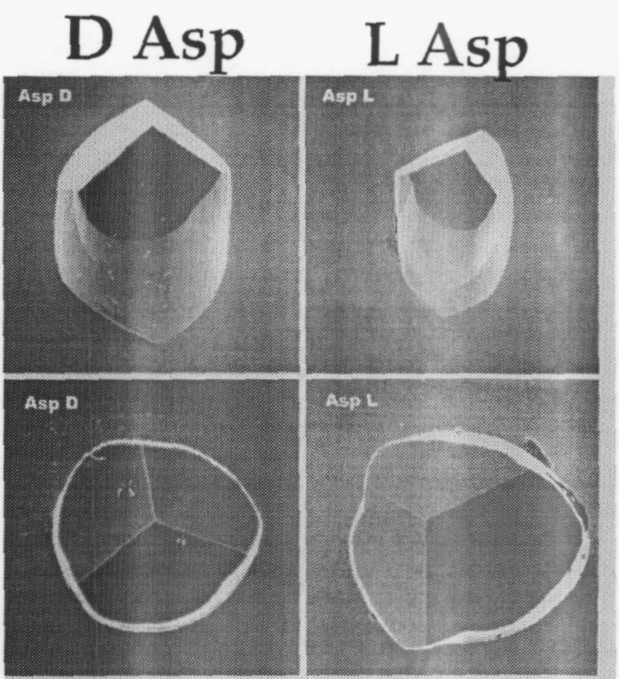

Fig. 3 - Crystal morphology with D- and L-aspartic acid

monolayer resolution of these techniques, no evidence for an adsorbed layer was observed. Because the AFM data unequivocally show that such an interaction must exist, our conclusion is that the aspartic acid is adsorbed to the $\{$ hk 0$\}$ faces, the same ones that are stabilized in the bulk crystals and that make up the step riser of the growth hillocks grown in the presence of aspartic acid. In a related project, we are modeling the structure of an aspartic acid adsorption layer on the $\{110\}$ and $\{1-10\}$ faces for both the $\mathrm{D}$ and the $\mathrm{L}$ forms, and we are preparing samples for optical and X-ray spectroscopy of those faces in aspartic acid-bearing solutions to determine the structural relationships between the crystal surface and the adsorbed organic layer.

We showed that the addition of amino acids had little effect on the step speeds for the two types of steps on the calcite surface. In contrast, the terrace width (critical length) varied continuously with increasing amino acid concentration until, at high concentration, the well defined step directions were lost as in Fig. 1. The results of this study demonstrate that the physical effect of the amino acids on the growth of calcite is to alter the surface energetics and not the step kinetics. In other words, modification of calcite by acidic amino acids is a thermodynamic effect, not kinetic .

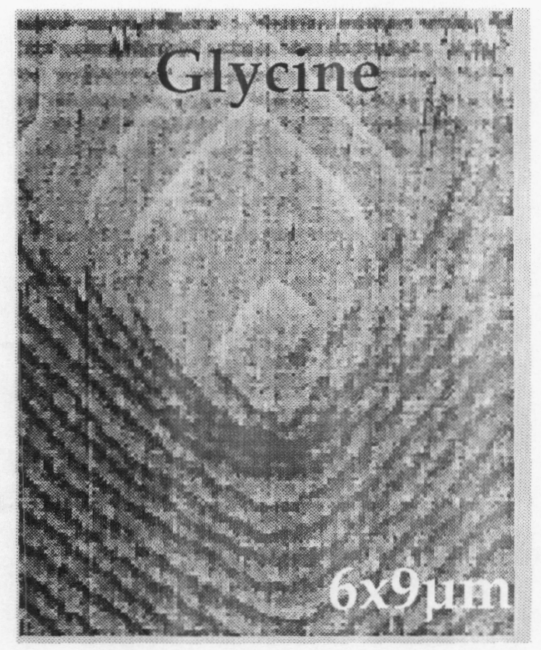

Fig. 4 - Growth hillock morphology with D- and L-aspartic acid

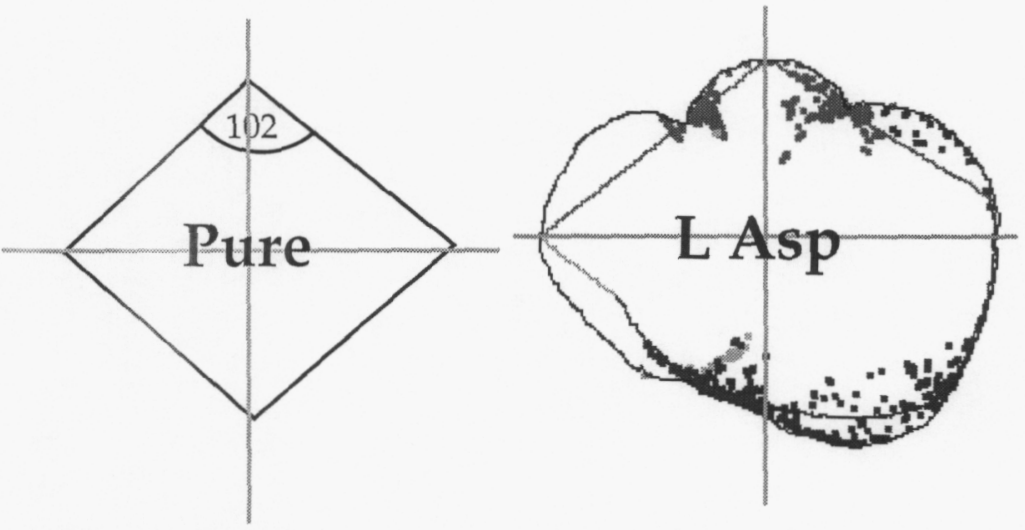

Fig.5 -Wulff plot showing orientational dependence of step edge energy for pure calcite and calcite with L-ASP. Solid colored lines show real crystal shape. Dots show derived step edge energy. Solid black lines are schematic in regions where crystal shape gives no information.

\section{Nucleation of calcite on patterned self-assembled monolayers}

A survey of biomineral structures quickly reveals that living organisms must control, with high fidelity, the location, orientation and crystallographic phase of crystals during nucleation. In order to explore the possibility that differences in surface functionality can be used to control these factors, we prepared patterned self-assembled monolayers (SAM) in which $10 \mu \mathrm{m}$ square patches of $\mathrm{COOH}$ terminated thiols were regularly placed amongst a methyl terminated background. We chose $\mathrm{COOH}$ terminated templates because this chemical group is hypothysized to be the active group on acidic amino acids that modifies calcite growth. As Fig. 6 shows, $100 \%$ of all calcite crystals nucleated on the $\mathrm{COOH}$ terminated patches. No calcite was found on the methyl background. The results of Aizenberg et al., $1999,{ }^{20}$ published shortly after we obtained these results, showed that many different functional groups could be used to induce calcite nucleation 
giving $100 \%$ control over both the location and the out of plane crystallographic orientation of the crystals. Future work should focus on measuring the dependence of nucleation rate on supersaturation in order to quantify the differences in the calcite/film interfacial energy for the various functional groups.

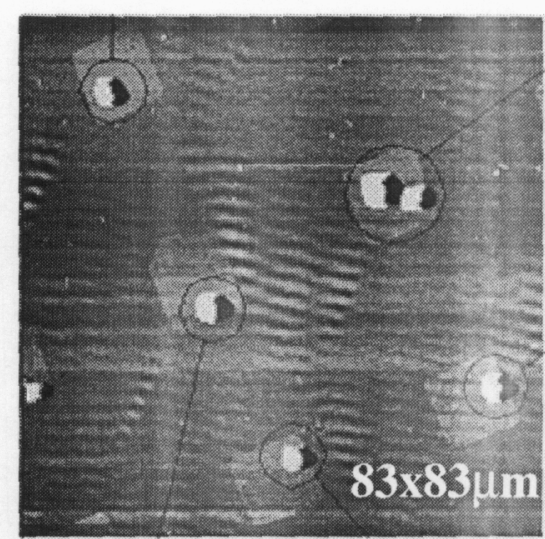

Fig. 6 - Chemical force microscopy image of calcite crystals nucleated on thiol selfassembled monolayer. Light orange squares are $\mathrm{COOH}$ terminated. Dark background is $\mathrm{CH}_{3}$ terminated.

\section{Conclusion}

The results of this study have advanced our understanding of calcite biomineralization and suggest a synthetic means of modifying growth. Our work on pure calcite set a rigorous foundation for investigating the physical effects of the organic fraction. The investigations of calcite growth in simple amino acid bearing solutions and calcite nucleation on carboxyl films showed that the major effect of the organic compounds is to alter the surface and interfacial energies, leaving the kinetics relatively unchanged. Our initial experiments with calcite nucleation on organic templates shows that variations in surface functionality can be used to control calcite growth presumably through modifications of the interfacial energy. Taken in total, the results of this work demonstrate that control of calcite growth by organic fractions can be achieved with even simple organic molecules and that the control mechanism is often modification of the surface energetics resulting in a new equilibrium thermodynamic state for the calcite system.

\section{References}

1 Addadi, L. \& Weiner, S. (1985). Interactions between acidic proteins and crystals: Stereochemical requirements in biomineralization. Proc. Natl. Acad. Sci. 82, 41104114 (1985).

2 Weiner, S. and Addadi, L. (1991) Acidic macromolecules of mineralized tissues: the controllers of crystal formation.

3 Young, Jeremy R., J.M. Didymus, P.R. Brown, B. Prins, S. Mann (1992). Crystal assembly and phylogenetic evolution in heterococcoliths. Nature, v. 356, p. 516-518.

4 Mann, S., Archibald, D. D., Didymus, J. M., Heywood, B. R., Meldrum, F. C., \& Wade, V. J. (1992). Biomineralization: Biomimetic potential at the inorganic-organic interface. MRS Bulletin XVII, 32-36.

5 Mann, S. (1993). Molecular tectonics in biomineralization and biomimetic materials chemistry. Nature, v. 365, p. 499-505.

6 Berman, A., Hanson, J., Leiserowitz, L., Koetzle, T. F., Weiner, S., \& Addadi, L., (1993). Biological control of crystal texture: A widespread strategy for adapting crystal properties to function. Science 259, 776-779.

7 Addadi, L., J. Moradian, E. Shay, N.G. Maroudas and S. Weiner (1987). A chemical model for the cooperation of sulfates and carboxylates in calcite crystal formation. Proc. Nat. Acad. Sci., v. 84 , p. $2732-2736$.

8 Berman, A., Ahn, D. J., Lio, A., Salmeron, M., Reichert, A., \& Charych, D., (1995). Total alignment of calcite at acidic polydiacetylene films: Cooperativity at the organic-inorganic interface. Science 259, 515-518 (1995).

9 Sikes, C.S., M.L. Yeung and A.P. Wheeler (1990). Inhibition of calcium carbonate and phosphate crystallization by peptides enriched in aspartic acid and phosphoserine. In Surface Reactive Peptides and Polymers: Discovery and Commercialization. C.S. Sikes and A.P. Wheeler, Eds. (ACS Books: Washington, 1990) ch. 5. 
10 Wheeler, A. P., Low, K. C., Sikes, C. S. (1990). $\mathrm{CaCO}_{3}$ crystal-binding properties of peptides and their influence on crystal growth. In Surface Reactive Peptides and Polymers: Discovery and Commercialization. C.S. Sikes and A.P. Wheeler, Eds. (ACS Books: Washington, 1990) ch. 6.

11 Burgess, S. K. \& Oxendine, S. L. (1995). A comparison of calcium binding in callinectes sapidus premolt and postmolt cuticle homogenates: Implications for regulation of biomineralization. Journal of Protein Chemistry 14, 655-664.

12 Mann, S. (1988). Molecular recognition in biomineralization. Nature 332, 119-124.

13 Berman, A., Addadi, L., \& Weiner, S. (1988). Interactions of sea-urchin skeleton macromolecules with growing calcite crystals - a study of intracrystalline proteins. Nature 331, 546-547.

14 Mann, S., Didymus, J. M.. Sanderson, N. P., Heywood, B. R., \& Samper, E. J. A. (1990). Morphological influence of functionalized and non-functionalized crystallization. J. Chem. Soc. Faraday Trans 86, 10, 1873-1880.

15 Mann, S., Archibald, D. D., Didymus, J. M., Douglas, T., Heywood, B. R., Meldrum, F. C., \& Reeves, N.J. (1993). Crystallization at inorganic-organic interfaces: biominerals and biomimetic synthesis. Science 261, 1286-1292.

16 Calvert, P. (1992). Biomimetic ceramics and composites. MRS Bulletin XVII, 37-40.

17 Didymus, J.M., S. Mann, N.P. Sanderson, P. Oliver, B.R. Heywood and E.J. Aso-Samper (1991). Modelling biomineralization: Studies on the morphology of synthetic calcite. In Mechanisms and Phylogeny of Calcification in Biological Systems. Eds. S. Suga and H. Nakara, Springer-Verlag. p. 267-271.

18 Vincent, J. (1990). Structural Biomaterials. Princeton University Press, Princeton, pp. 244.

19 Holland, H.D., B. Lazar and M. McCaffrey (1986). Evolution of the atmosphere and oceans. Science, v. 320, p. 27-33.

20 Crenshaw, M.A. (1990). Biomineralization Mechanisms, In Skeletal Biomineralization: Patterns, Processes and Evolutionary Trends. Ed. J.G. Carter, Van Nostrand, New York. p. 1-9.

21 Weiner, S., Traub, W., and Lowenstam, H. A. (1983) Organic matrix in calcified exoskeletons. In Biomineralization and Biological Metal Accumulation (eds. P. Westbroek and E. W. de Jong). 205-224, Reidel, Dordrecht.

22 Belcher, A.M., Wu, X.H.. Christensen, R.J., Hansma, P.K., Stucky, G.D. and Morse, D.E., (1996). Control of crystal phase switching and orientation by soluble mollusc-shell proteins. Nature, 381, 56-58.

23 Walters, D.A., Smith, B.L.. Paloczi, G.T., and others (1997) Modification of calcite crystl growth by abalone shell proteins: An atomic force microscopy study. Biophys. J. 72, 1425-1433.

24 Thompson and Mitchenfilder, pers. comm.

25 Wierzbicki, A., Sikes, C.S., Madura, J.D., and Drake, (1994), Calcif. Tissue Int., v. 54, p. 133141. 